\title{
Tuber melanosporum shapes nirS-type denitrifying and ammonia-oxidizing bacterial communities in Carya illinoinensis ectomycorrhizosphere soils
}

\author{
Zongjing Kang $^{1,2}$, Jie Zou ${ }^{1,2}$, Yue Huang ${ }^{1,2}$, Xiaoping Zhang ${ }^{1,2}$, Lei Ye ${ }^{1}$, Bo Zhang $^{1}$, Xiaoping Zhang $^{2}$, Xiaolin Li $^{2}$ \\ Corresp. 1 \\ ${ }^{1}$ Soil and Fertilizer Institute, Sichuan Academy of Agricultural Sciences, Chengdu, China \\ 2 Department of Microbiology, College of Resources, Sichuan Agricultural University, Chengdu, China \\ Corresponding Author: Xiaolin Li \\ Email address: kerrylee_tw@sina.com
}

Background. NirS-type denitrifying bacteria and ammonia-oxidizing bacteria (AOB) play a key role in the soil nitrogen cycle, which may affect the growth and development of underground truffles. We aimed to investigate nirS-type denitrifying bacterial and AOB community structures in the rhizosphere soils of Carya illinoinensis seedlings inoculated with the black truffle (Tuber melanosporum) during the early symbiotic stage.

Methods. The $C$. illinoinensis seedlings inoculated with or without $T$. melanosporum were cultivated in a greenhouse for six months. Next-generation sequencing (NGS) technology was used to analyze nirS-type denitrifying bacterial and $A O B$ community structures in the rhizosphere soils of these seedlings.

Additionally, the soil properties were determined.

Results. The results indicated that the abundance and diversity of AOB were significantly reduced due to the inoculation of $T$. melanosporum, while these of nirS-type denitrifying bacteria increased significantly. Proteobacteria were the dominant bacterial groups, and Rhodanobacter, Pseudomonas, Nitrosospira and Nitrosomonas were the dominant classified bacterial genera in all the soil samples. Pseudomonas was the most abundant classified nirS-type denitrifying bacterial genus in ectomycorrhizosphere soils whose relative abundance could significantly increase after $T$. melanosporum inoculation. A large number of unclassified nirS-type denitrifying bacteria and AOB were observed. Moreover, T. melanosporum inoculation had little effect on the $\mathrm{pH}$, total nitrogen (TN), nitrate-nitrogen $\left(\mathrm{NO}_{3}{ }^{-} \mathrm{N}\right)$ and ammoniumnitrogen $\left(\mathrm{NH}_{4}{ }^{+}-\mathrm{N}\right)$ contents in ectomycorrhizosphere soils. Overall, our results showed that nirS-type denitrifying bacterial and $A O B$ communities in $C$. illinoinensis rhizosphere soils were significantly affected by $T$. melanosporum on the initial stage of ectomycorrhizal symbiosis, without obvious variation of soil $\mathrm{N}$ contents. 
1 Tuber melanosporum shapes nirS-type denitrifying and

2 ammonia-oxidizing bacterial communities in Carya

3 illinoinensis ectomycorrhizosphere soils

4

5

6 Zongjing Kang ${ }^{1,2 \#}$, Jie Zou ${ }^{1,2 \#}$, Yue Huang ${ }^{1,2}$, Xiaoping Zhang ${ }^{1,2}$, Lei Ye ${ }^{1}$, Bo Zhang ${ }^{1}$, Xiaoping

7 Zhang ${ }^{2}$, Xiaolin $\mathrm{Li}^{1 *}$

$8 \quad{ }^{1}$ Soil and Fertilizer Institute, Sichuan Academy of Agriculture Sciences, Chengdu, China

$9 \quad 2$ Department of Microbiology, College of Resources, Sichuan Agricultural University, Chengdu,

10 China

11 \# Zongjing Kang and Jie Zou contributed equally to the work.

13 *Corresponding Author: Xiaolin Li

14 Email address: kerrylee_tw@sina.com 
16

17

18

\section{Abstract}

Background. NirS-type denitrifying bacteria and ammonia-oxidizing bacteria (AOB) play a key role in the soil nitrogen cycle, which may affect the growth and development of underground truffles. We aimed to investigate nirS-type denitrifying bacterial and AOB community structures in the rhizosphere soils of Carya illinoinensis seedlings inoculated with the black truffle (Tuber melanosporum) during the early symbiotic stage.

Methods. The C. illinoinensis seedlings inoculated with or without T. melanosporum were cultivated in a greenhouse for six months. Next-generation sequencing (NGS) technology was used to analyze nirS-type denitrifying bacterial and $\mathrm{AOB}$ community structures in the rhizosphere soils of these seedlings. Additionally, the soil properties were determined.

Results. The results indicated that the abundance and diversity of AOB were significantly reduced due to the inoculation of T. melanosporum, while these of nirS-type denitrifying bacteria increased significantly. Proteobacteria were the dominant bacterial groups, and Rhodanobacter, Pseudomonas, Nitrosospira and Nitrosomonas were the dominant classified bacterial genera in all the soil samples. Pseudomonas was the most abundant classified nirS-type denitrifying bacterial genus in ectomycorrhizosphere soils whose relative abundance could significantly increase after T. melanosporum inoculation. A large number of unclassified nirS-type denitrifying bacteria and AOB were observed. Moreover, T. melanosporum inoculation had little effect on the $\mathrm{pH}$, total nitrogen $(\mathrm{TN})$, nitrate-nitrogen $\left(\mathrm{NO}_{3}{ }^{-}-\mathrm{N}\right)$ and ammonium-nitrogen $\left(\mathrm{NH}_{4}{ }^{+}-\mathrm{N}\right)$ contents in ectomycorrhizosphere soils. Overall, our results showed that nirS-type denitrifying bacterial and AOB communities in C. illinoinensis rhizosphere soils were significantly affected by $T$. melanosporum on the initial stage of ectomycorrhizal symbiosis, without obvious variation of soil $\mathrm{N}$ contents. 
39

40 41

4 43

44 45

\section{Introduction}

Tuber (Ascomycota, Pezizales) commonly known as the truffle, is an edible fungus which can form symbiotic relationships with plants. To date, more than 200 species of truffles have been discovered worldwide (Bonito et al., 2011), particularly in Sweden, France, Italy, Hungary, Spain, the United Kingdom, and Russia (Wedén et al., 2004). Tuber melanosporum, native in France, Italy and Spain, is a valuable and rare species of Tuber in the market (Donnini et al., 2014). T. melanosporum attracted people primarily by its unique aroma compounds. As ectomycorrhizal fungi, truffles need to form symbiotic association with the host plant to complete their life cycle (Kües et al., 2011). Recently, the cultivation of T. melanosporum (as well as other species including T. aestivum Vittad., T. borchii Vittad., and T. indicum) has been conducted worldwide by planting truffle-mycorrhized plant hosts in nurseries (Reyna et al., 2014), and yet studies on the cultivation of this black truffle species in China are seldom reported.

Truffles can form symbiotic relationships with trees from several genera, including Corylus, Quercus, Abies Pinus, Populus and Salix (Healy et al., 2016; Wan et al., 2016). The pecan tree, Carya illinoinensis (Wangenh.) K. Koch, is an indigenous and economically important tree that grows naturally in moist bottom-land habitats in the United States (Sparks, 1992). However though endemic to the Mississippi basin, C. illinoinensis is now cultivated globally (Wakeling et al., 2001; Ruan et al., 1992). Tuber lyonii Butters was the first truffle species described in symbiotic association with the pecan tree (Trappa et al., 1996). Bonito et al. (2011) hypothesized that pecan orchards could be managed to optimize both truffle and pecan production simultaneously. In general, the utilization of $C$. illinoinensis as a host plant for T. melanosporum has good application prospects and is worthy of study. 
61 Soil microorganisms and physicochemical properties in the rhizosphere of host plant can change 62 and vary with the growth of truffles, from the occurrence of ectomycorrhizae to the formation of 63 their mature fruiting bodies (Ponce et al., 2014; Barbieri et al., 2007; Garcia-Barreda et al., 2017).

64 The microbial communities of ectomycorrhizosphere soils are verified to be different from that of 65 rhizosphere soils in both artificial conditions and the wild (Fu et al., 2016; Li et al., 2018). There

66

67

were numerous classified and unclassified microorganisms detected in the ectomycorrhizosphere soils of Tuber (Garcia-Barreda et al., 2012), which made it difficult to analyze the taxonomy and function of all the bacteria simultaneously. Paracoccus, Pseudomonas, Rhizobium, Bacillus, and Nitrosomonadales were some possible denitrifying bacteria and ammonia-oxidizing bacteria (AOB) (Yoshida et al., 2010; Purkhold et al., 2000) already detected in the ectomycorrhizae and ectomycorrhizosphere soil of Tuber-host associations (Yang et al., 2019; Li et al., 2019; Mello et al., 2013). Nevertheless, the distribution of denitrifying bacteria and the structure of AOB communities in ectomycorrhizosphere soils stay unclear.

The nitrogen $(\mathrm{N})$ cycle is one of the most important nutrient cycles in an ecosystem (Thamdrup, 2012), which is vital for host plants and Tuber. Both denitrification and ammonia oxidation are important biological processes in the $\mathrm{N}$ cycle. Denitrification is the main pathway of $\mathrm{N}_{2} \mathrm{O}$ release in farmland ecosystems (Conrad, 1997), and an important process that reduces $\mathrm{N}$ pools in farmland soils (Seitzinger et al., 2006). By denitrification, denitrifying microorganisms gradually reduce the nitrates or nitrous acid in the environment to gaseous products $\left(\mathrm{NO}, \mathrm{N}_{2} \mathrm{O}\right.$, and $\left.\mathrm{N}_{2}\right)$ under multistep enzymatic catalysis. Most soil denitrification is performed by denitrifying microbes, including bacteria, fungi, and archaea (Shapleigh, 2006). Denitrification-related enzymes containing nitrate, nitrite, $\mathrm{NO}$, and $\mathrm{N}_{2} \mathrm{O}$ reductase, can be expressed by certain denitrifying bacteria such as Pseudomonas denitrificans and Bacillus stearothermophilus (Gregory et al., 2003). The nitrite 
84 reductase functional gene, which control the catalyzing of the reduction of nitrite to nitric oxide, 85 is the main molecular marker in denitrifying bacteria research (Braker et al., 2000). Nitrite 86 reductase has two different structural forms, one of them contains copper $(\mathrm{Cu}-n i r)$ and is encoded 87 by the nirK gene, while the other contains the heme CD1 (cd1-nir) is encoded by nirS gene containing (Zumft, 1997). More nirS gene are detected than nirK gene in most soil samples, and nirS-type denitrifying bacteria species in the environment are affected by factors such as water, plants, etc (Azziz et al., 2017). As the main driver of the ammonium oxidation process, AOB has long been a focal and functional focus in environmental microbial ecology (Kowalchuk et al., 2001). The AOB in $\beta$-Proteobacteria and $\gamma$-Proteobacteria has been long considered to be the most active in ammonium oxidation in soils. The oxidation of ammonia to nitrite is a rate-limiting step of nitrification controlled by many AOB ammonia monooxygenase (amo $A$ ) genes. These genes were widely involved in the study of the relative abundance of AOB in ecosystems (Purkhold et al., 2000; Wang et al., 2011). The efficiency of nitrification and denitrification in soils were related to the number of microbial functional genes. The community structure of ammonia-oxidizing microorganisms, however could in return be affected by the concentration of ammonium nitrogen and organic matter (Petersen et al., 2012). Structures of nirS-type denitrifying bacterial and AOB community in Tuber ectomycorrhizosphere soils is unclear. Only few studies have focused on the relationship between these bacteria and properties of the ectomycorrhizosphere soils.

Therefore in our study, we infected C. illinoinensis with the spores of T. melanosporum and tracked the formation of mycorrhizae during the next six months of cultivation. We also did Nextgeneration amplicon sequencing for nirS and amoA genes, to analyze the denitrification and ammonia oxidation microbial community structures in rhizosphere soils. Furthermore, the physicochemical soil properties in the rhizosphere of $C$. illinoinensis seedlings were determined. 
107 The study aims to investigate nirS-type denitrifying bacterial and AOB community structures

108 involving in the ammonium oxidation and denitrification processes in the $T$. melanosporum

109 ectomycorrhizosphere soils.

\section{Materials \& Methods}

\section{Cultivation of sterile $C$. illinoinensis seedlings}

112 Seeds of $C$. illinoinensis were soaked in fresh-water for about $20 \mathrm{~h}$ and sterilized with $0.3 \%$

113 potassium permanganate for $30 \mathrm{~min}$, then the seeds were rinsed with distilled water until the last

114 wash solution became colorless. In order to increase the germination rate, the seeds were stored in

115 the sand which had been sterilized for $90 \mathrm{~min}$ at $121^{\circ} \mathrm{C}$ in an autoclave. One month later, the

116 germinated $C$. illinoinensis seeds were sown in a plastic container filled with the sterilized

117 substrate (vermiculite, perlite and water at a ratio of 1:1:1, v/v/v) (Fig. S1) (Li et al., 2017). The

118 plastic container with seeds was then placed in a natural light plastic greenhouse and watered with

119 sterile water, to maintain a soil moisture content of $25 \%$. The temperature of the greenhouse was

$12023^{\circ} \mathrm{C}-25^{\circ} \mathrm{C}$ in daytime and $16^{\circ} \mathrm{C}-20^{\circ} \mathrm{C}$ at night. The well-grown $C$. illinoinensis seedlings with

121 similar plant height and stem thickness were selected for inoculation.

122 Truffle inoculation treatment

123 T. melanosporum ascocarps were purchased from French truffle producing areas and used as spore

124 inoculum. The ascocarps were washed with sterile water and their surface sterilized by burning

125 briefly with $75 \%$ alcohol. Then the ascocarps were soaked in sterile water to stimulate spores

126 release and germination (Semeniuk, 2008). Finally, the treated T. melanosporum ascocarps were

127 smashed and blended using food chopper to obtain their paste. Next, the substrates with peat,

128 vermiculite, perlite organic soil and water at a ratio of 1:1:1:0.9 (v/v/v/v) were prepared and

129 sterilized for $90 \mathrm{~min}$ at $121^{\circ} \mathrm{C}$ in an autoclave. The sterilized substrate (total nitrogen $2.05 \mathrm{~g} / \mathrm{kg}$, 
130 nitrate-nitrogen $37.50 \mathrm{mg} / \mathrm{kg}$ and ammonium-nitrogen $20.16 \mathrm{mg} / \mathrm{kg}$ ) was filled into nursery pots

131 and $1.5 \mathrm{~g}$ of the paste inoculum was mixed into the substrate of each pot, then one sterile seedling

132 was transplanted into each nursery pot. Thirty seedlings inoculated with T. melanosporum were

133 named group I. At the same time, an equivalent number of $C$. illinoinensis seedlings were

134 transplanted into nursery pots without T. melanosporum inoculum, named group II . Each group

135 had thirty replicates to ensure the survival of enough seedlings after 6 months cultivation. All pots

136 were maintained in a greenhouse under the same conditions without fertilization, and they were

137 watered with tap water every three days at 6:00 pm for 6 month (Geng et al., 2009).

138 Sampling strategy and soil analyses

139 Eight pots of group I and four pots of group II were randomly selected, and roots of these

140 seedlings were observed under a microscope. Morphological and anatomical analysis revealed that

141 the four seedlings in group $\mathbb{I}$ were not colonized by ectomycorrhizal fungi, and only 4 of the 8

142 seedlings in group I inoculated with truffle spores, showed ectomycrrhizae formation (Fig. 1)

143 (Marozzi et al., 2017). The four pots of group I colonized by T. melanosporum were used as

144 experimental materials, and the four pots of group $I$ were used as controls, thus, each experimental

145 treatment had four replicates. Ectomycorrhizosphere soils (rhizosphere soils of C. illinoinensis

146 seedlings inoculated with $T$. melanosporum) and rhizosphere soils (rhizosphere soils of $C$.

147 illinoinensis seedlings without inoculating) samples were sampled and placed into $2 \mathrm{~mL}$ EP tubes.

148 The samples were cooled rapidly using liquid nitrogen and stored at $-80^{\circ} \mathrm{C}$. The remaining soils

149 around the $C$. illinoinensis roots were air dried for soil property analysis, including $\mathrm{pH}$, organic

150 matter (OM), available potassium (AK), total nitrogen (TN), available phosphorus (AP), nitrate-

151 nitrogen $\left(\mathrm{NO}_{3}{ }^{-}-\mathrm{N}\right)$ and ammonium-nitrogen $\left(\mathrm{NH}_{4}{ }^{+}-\mathrm{N}\right)$, which were determined following the 
152 methods described in previous studies (Lu, 1999; Li et al., 2017). Ectomycorrhizosphere soils of 153 C. illinoinensis colonized with T. melanosporum were labeled as "FH" from Chines name of the

154 Tuber, "Faguo Heibao", and the rhizosphere soils of the $C$. illinoinensis seedlings without $T$. 155 melanosporum inoculation were labeled as "CK" standing for Control Check.

\section{DNA extraction, PCR amplification, and MiSeq sequencing}

157 DNA from rhizosphere soils was extracted using a Soil DNA Kit (D5625-01, Omega Bio-tek Inc., 158 Norcross, GA, USA) following the manufacturer's instructions. The DNA concentration and 159 purity were measured on $1 \%$ agarose gels, adjusted to $1 \mathrm{ng} / \mu \mathrm{L}$ using sterile water and stored at $16020^{\circ} \mathrm{C}$.

161 The universal primers Cd3aF (5'-GTSAACGTSAAGGARACSGG-3') (Michotey et al., 2000) 162 and R3cd (5'-GASTTCGGRTGSGTCTTGA-3') (Throbäck et al., 2004) were used to amplify 163 nirS-type denitrifying bacteria in PCR. The reaction consisted of 10 ng DNA template, $4 \mu \mathrm{L}$ 164 FastPfu buffer, $2 \mu \mathrm{L}$ dNTPs $\left(2.5 \mathrm{mmol} \cdot \mathrm{L}^{-1}\right), 0.4 \mu \mathrm{L}$ FastPfu polymerase, $0.8 \mu \mathrm{L}$ forward primer $(5$ $\left.165 \mu \mathrm{mol} \cdot \mathrm{L}^{-1}\right)$, and $0.8 \mu \mathrm{L}$ reverse primer $\left(5 \mu \mathrm{mol} \mathrm{L}^{-1}\right)$, diluted to $20 \mu \mathrm{L}$ with $\mathrm{ddH}_{2} \mathrm{O}$. The reaction 166 program was set as follows: pre-denaturation at $95^{\circ} \mathrm{C}$ for $4 \mathrm{~min}$, followed by 28 cycles of 167 denaturation at $95^{\circ} \mathrm{C}$ for $40 \mathrm{~s}$, annealing at $56^{\circ} \mathrm{C}$ for $30 \mathrm{~s}$, extension at $72^{\circ} \mathrm{C}$ for $40 \mathrm{~s}$, and then final 168 extension at $72^{\circ} \mathrm{C}$ for $10 \mathrm{~min}$. The universal primers b-amoA-1F $\left(5^{\prime}-\right.$ 169 GGGGTTTCTACTGGTGGT-3') and b-amoA-2R (5'-CCCCTCKGSAAAGCCTTCTTC-3') 170 (Mao et al., 2011) were used to amplify the AOB in a $30 \mu \mathrm{L}$ reaction system, which were consisted 171 of $15 \mu \mathrm{L} 2 \times$ Ex Taq MasterMix, $1.2 \mu \mathrm{L}$ forward and reverse primers $(10 \mu \mathrm{mol} / \mathrm{L}), 3 \mu \mathrm{L}$ DNA 172 template and $9.6 \mu \mathrm{L}$ RNase-free water. Samples were amplified by subjecting them to the 173 following PCR program: $95^{\circ} \mathrm{C}$ for 3 min followed by 40 cycles at $95^{\circ} \mathrm{C}$ for $60 \mathrm{~s}, 55^{\circ} \mathrm{C}$ for $45 \mathrm{~s}$ and $17472^{\circ} \mathrm{C}$ extension for $60 \mathrm{~s}$. The samples were then mixed and analyzed by $1.5 \%$ agarose gel 
175 electrophoresis, after which the PCR product was recovered using a gel recovery kit (Axygen,

176 USA) and eluted with Tris- $\mathrm{HCl}$ and 1.5\% agarose gel electrophoresis (Kim et al., 2011). According

177 to the preliminary quantitative electrophoresis results, PCR products were quantified using

178 QuantiFluor ${ }^{\mathrm{TM}}$-ST Blue Fluorescence Quantitation System (Promega, USA), after which the

179 proportions were mixed according to template concentration for each sample. Finally, these 180 samples stored at $-80^{\circ} \mathrm{C}$.

181 High throughput sequencing was conducted at Shanghai Majorbio Bio-pharm Technology Co.,

182 Ltd. and sequenced according to manufacturer's recommendations with the Illumina MiSeq 183 sequencing platform. Raw data were submitted to the Sequence Read Archive (SRA) database 184 with the accession number SRR10522644-SRR10522659.

185 High-throughput data analysis and statistical analysis

186 Paired-end reads were obtained, and paired-end reads that overlapped were merged using FLASH 187 (Version 1.2.11) (Tanja \& Salzberg, 2011). The high-quality sequences with mismatch rate of 188 overlap sequence lower than $20 \%$ and with barcode and primer sequence were filtered by QIIME 189 (Version 1.8.0) and Trimmomatic software (Caporaso et al., 2010), then correct sequence 190 direction. Uparse (Version 7.0.1090) software was used to analyze the high-quality sequences, and 191 these sequences with $\geqslant 97 \%$ similarity were clustered to the same OTU (Operational Taxonomic 192 Units) (Edgar, 2013). A representative sequence for each OTU was screened for further annotation, 193 and the taxonomic analysis of OTUs was performed using the RDP Classifier (Version 2.11; 194 http://sourceforge.net/projects/rdp-classifier/) (Wang et al., 2007) based on the FunGene 195 (Release 7.3; http://fungene.cme.msu.edu/) database. Mothur (Version 1.30.2) was used to divided 196 OTUs, and alpha diversity analysis of nirS-type denitrifying bacterial and AOB population 197 (Coverage, Chao1, ACE, Shannon and Simpson index) were performed based on these OTUs. 
198 Source code for the OTUs data is available at: https://github.com/catherinekang/bacterial199 community.git. Moreover, a rarefaction curve was used to evaluate the representativeness of 200 sequencing amount for the diversity of the original nirS-type denitrifying bacteria or the AOB. In 201 addition, barplots based on the R software (Version 3.1.3) (Core et al., 2011) were utilized to 202 cluster and analyze the phylum and genus to share the taxonomic composition of the soil microbial 203 communities. Principle component analysis (PCA) and clustering analysis were used to reflect the 204 beta diversity.

205 Alpha diversity estimators, soil properties and relative abundance of the taxa of AOB and nirS206 type denitrifying bacteria between the two treatments were compared with independent $t$-test, 207 which was performed in SPSS v21.0 (IBM Inc., Armonk, NY, USA). All the data were presented 208 as the mean value \pm standard deviation (SD) of the four biological replicates in each treatment 209 group. All the significant differences were assessed at $P<0.05$.

\section{Results}

\section{Soil property analysis}

212 The results of soil properties showed that the nitrate-nitrogen and available potassium contents of 213 FH were slightly higher than those of $\mathrm{CK}$, and there were no significant different in $\mathrm{pH}$, organic 214 matter, available potassium, total nitrogen, available phosphorus, nitrate-nitrogen and ammonium215 nitrogen between CK and FH (Table. 1).

\section{AOB diversity analysis}

217 A total of 123,091 reads were obtained from the 8 samples after quality control procedures, most 218 of which were $401-500 \mathrm{bp}$, and there were 11,990-19,959 reads in each sample (Fig. 2a). All the 219 sequences were clustered into 251 OTUs, and the two treatments share 47 OTUs. The number of 
220 unique OTUs which can only be detected in FH (77) was smaller than the unique OTUs which can 221 only be detected in CK (127) (Fig. 3a).

222 As shown in Table 2, the coverage in the two treatments were 99\%, indicating that we sequenced 223 ammonia monooxygenase genes at the proper depth and the data were reliable. The richness 224 indices such as $\mathrm{ACE}(P=0.049)$ and Chaol $(P=0.043)$ estimators in CK was significantly greater 225 than these in FH. Shannon diversity in the two treatments ranged from 1.32 to 1.62 , and was 226 significantly greater in $\mathrm{CK}$ treatment $(P=0.047)$, however, there was no significant difference 227 between FH and CK in the Simpson index and the observed species (OTU). For the observed 228 species, Shannon, Chao1, and ACE of FH were lower than those of CK, which showed that the 229 richness and diversity of $\mathrm{AOB}$ in $\mathrm{FH}$ was significantly lower than that in $\mathrm{CK}(P<0.05)$ (Table. 230 2).

\section{Taxonomic analyses of $\mathbf{A O B}$}

232 As shown in Figure 4a, the observed species mainly belonged to two phyla, and Proteobacteria 233 was the most abundant in each treatment. The average relative abundance of Proteobacteria in CK $234(98.59 \%)$ was significantly greater than that in $\mathrm{FH}(84.93 \%)(P=0.049)$ (Table. 3$)$.

235 The results of classification showed that 251 OTUs were separated into more than six genera 236 (Fig. 5a). The primary three genera in FH treatment were Nitrosospira (57.90\%), Nitrosomonas $237(25.12 \%)$ and unclassified bacteria (15.07\%); while those in CK were Nitrosospira (55.38\%), 238 Nitrosomonas (39.99\%) and an unclassified genus belong to Betaproteobacteria (1.93\%) (Table. 239 4). Moreover, the relative abundance of Nitrosospira in both treatments was approximately the 240 same, while the relative abundance of Nitrosomonas in CK was slightly greater than that in FH. 241 Nitrosococcus was detected in CK, with significantly higher relative abundance than that in $\mathrm{FH}(P$ 
$242=0.046$ ). Nevertheless, the most abundant unclassified AOB genus in FH was significantly more

243 abundant than that in $\mathrm{CK}(1.41 \%)(P=0.005)$.

244 NirS-type denitrifying bacterial diversity analysis

245 A total of 139,493 reads were obtained from the 8 samples after quality control procedures, most 246 of which the sequencing length was 301-400 bp, and there were 10,424-19,961 reads in each 247 sample (Fig. 2b). All the sequences from the two treatments were clustered into 750 OTUs, which 248 were utilized to form a histogram of genera and phyla. Moreover, there were a total of 193 OTUs 249 shared by two treatments and the number of unique OTUs detected in FH (311) was more than the 250 unique OTUs detected in CK (246) (Fig. 3b).

251 The coverage of the denitrifying bacterial communities in the two treatments was $99 \%$ (Table. 252 2). The $\operatorname{ACE}(P=0.042)$ and Chaol $(P=0.048)$ estimators revealed that the richness of nirS-type 253 denitrifying bacteria in FH was significantly greater than that in CK. The Simpson index of two 254 treatments was similar, and the number of observed species of FH was slightly higher than that of 255 CK without significant difference. And the Shannon index of FH was significantly higher than that 256 of CK $(P=0.037)$ (Table. 2). The results demonstrated that the richness and diversity of nirS-type 257 denitrifying bacteria were significantly increased with T. melanosporum inoculation. Moreover, 258 the observed species of nirS-type denitrifying bacteria were far more than AOB in both treatments 259 (Fig S2), the Shannon, Chao1 and ACE index of nirS-type denitrifying bacteria were much higher 260 than AOB.

\section{Taxonomic analyses of nirS-type denitrifying bacterial communities}

262 As shown in Figure 4b, at the phylum level, the most abundant were unclassified bacteria and no 263 rank bacteria, followed by Proteobacteria. The average proportions of Proteobacteria in the two 264 treatments were 9.49\% (CK) and 8.69\% (FH), with Proteobacteria and an unclassified bacteria 
265 phylum being slightly more abundant in CK than in FH (Table. 3). Nevertheless, there was no 266 significant difference in the relative abundance of the dominant phyla between FH and CK.

267 The results showed that these 750 OTUs belonged to more than nine genera, and the most 268 abundant classified genera were Pseudomonas, Rhodanobacter, Magnetospirillum and Rubrivivax 269 (Fig 5b). The main classified genera in FH were Pseudomonas (0.46\%), while the main classified 270 genus in CK was Rhodanobacter (0.33\%), and the relative abundance of Pseudomonas of FH was 271 significantly higher than that of $\mathrm{CK}(P=0.017)$ (Table. 4). The relative abundance of the no rank 272 bacterial genus was similar in FH and CK, without significant difference. However, the relative 273 abundance of two unclassified genera observed in $\mathrm{FH}$, belonging to Gammaproteobacteria $(P=$ $2740.027)$ and Betaproteobacteria $(P=0.015)$, were significantly lower than those observed in CK.

\section{Principle component analysis (PCA)}

276 The Unifrac-PCA analysis was used to visualize the similarities and differences of the bacterial 277 component in different soil samples. The shorter distance between two samples means more 278 similar nirS-type denitrifying bacterial and AOB communities in the different samples, and the 279 different shaded circles represented confidence ellipses. The results showed that both AOB and 280 nirS-type denitrifying bacteria in the FH were not similar to CK. In Figure 6, the distance between $281 \mathrm{FH}$ and $\mathrm{CK}$ in $\mathrm{AOB}$ was greater than the distance between them in nirS-type denitrifying bacteria, 282 which could indicate that the difference of $\mathrm{AOB}$ communities between FH and CK was greater 283 than that of nirS-type denitrifying bacterial communities between them.

\section{Discussion}

285 This experiment amplified nirS and amoA genes partner to detected the denitrifying bacterial and 286 ammonia-oxidizing bacterial (AOB) communities from the rhizosphere soil of $C$. illinoinensis with 287 or without T. melanosporum inoculation. The study also explored the impacts of T. melanosporum 
288 inoculation on the nitrogen cycling bacteria in microecology of $C$. illinoinensis rhizosphere within 2896 months after inoculation.

290 Results of PCA analysis showed a significant difference of nirS-type denitrifying bacterial and 291 AOB communities between ectomycorrhizosphere soil and rhizosphere soil. This was in 292 accordance with the previous finding that the composition and function of bacterial communities 293 in ectomycorrhizosphere soil could be altered by the formation of ectomycorrhizae (Jung et al., 294 2012). In our study, the total nitrogen, nitrate-nitrogen and ammonium-nitrogen contents of 295 ectomycorrhizosphere soil were not significantly different from rhizosphere soil similarly to the 296 contents of other determined properties. Previous studies reported that the ectomycorrhizal fungi 297 could increase available nitrogen in forest soil by producing enzymes or organic acids, 298 accelerating plant litter decomposition, and soil mineral dissolution (Sterkenburg et al., 2018; 299 Lindahl et al., 2006). The contrasting results from our study, however, suggested that the 300 ectomycorrhizae of $T$. melanosporum had little impact on the soil properties in the host plant 301 rhizosphere which did not contain plant litter at the initial stage of inoculation.

302 Moreover, the richness and diversity of $\mathrm{AOB}$ in the ectomycorrhizosphere soil were 303 significantly lower than those in rhizosphere soil $(P<0.05)$. The Proteobacteria was the most 304 abundant AOB in both ectomycorrhizosphere soil (84.93\%) and rhizosphere soil (98.59\%), which 305 was consistent with the in forest soils (Rosch et al., 2002). The most abundant genera of AOB 306 were Nitrosospira and Nitrosomonas. Li et al. (2018) reported that the Nitrosospira and 307 Nitrosomonas were the most abundant AOB in ectomycorrhizosphere soil of Pinus massoniana 308 Lamb colonized by Pisolithus tinctorius under field condition, which is basically the same with 309 the findings of our study. In addition, the relative abundance of Nitrosococcus and an unclassified 310 AOB genus of Betaproteobacteria in ectomycorrhizosphere soils was significantly greater than 
311 that in rhizosphere soils while another unclassified genus was significantly lower than that in

312 rhizosphere soils $(P<0.05)$. The soil moisture might have an indirect effect on AOB communities

313 by changing the availability and mobility of nitrogen in the substrate (Gleeson et al., 2010; Hu et

314 al., 2015). However, C. illinoinensis seedlings in two treatments were watered equally in this work.

315 Previous studies have illustrated that the diversity of bacterial communities reduced in the brûlés

316 (an area devoid of herbaceous cover) and ectomycorrhizosphere soil (Mello et al., 2013; Zhang et

317 al., 2019). Nevertheless, some bacterial genera in ectomycorrhizosphere soils were significantly

318 more abundant than those in rhizosphere soils, such as Mesorhizobium, Reyranena,

319 Rhizomicrobium and Nordella (Li et al., 2017). These findings may imply that the $T$.

320 melanosporum ectomycorrhizae have different effect on different AOB genera (Doornbos et al.,

321 2012), and the richness and diversity of the AOB in rhizosphere soils were reduced by $T$.

322 melanosporum inoculation in general, though the ectomycorrhizae of T. melanosporum indeed

323 affect the relative abundance of Nitrosospira and Nitrosomonas little during early symbiotic stage.

324 In terms of the structural analysis nirS-type denitrifying bacterial community, Proteobacteria

325 was the dominant group both in rhizosphere and ectomycorrhizosphere soils. Previous studies

326 showed that most of the denitrifying bacteria which were detected in crop rhizosphere soils and

327 arable land soils belong to Proteobacteria (Chang et al., 2012; Hui et al., 2010; Hou et al., 2018),

328 which corroborates our results. Our work also showed that the Rhodanobacter, Pseudomonas,

329 Magnetospirillum and Rubrivivax were the dominant classified bacterial genera in all the soil

330 samples, which were detected in plant rhizosphere soils and arable land soils frequently (Cho et

331 al., 2017; Yu et al., 2018; Wen et al., 2016). The richness and diversity of nirS-type denitrifying

332 bacterial communities in ectomycorrhizosphere soil were significantly greater than those in

333 rhizosphere soil $(P<0.05)$. The land use and fertilizer regimes affected the biological activity of 
334 denitrifying bacteria (Hui et al., 2010), and the abundance of Rhodanobacter was sensitive to $\mathrm{pH}$

335 (Green et al., 2010). However, the differences in soil properties between two treatments were not

336 significant in the present study, which may illustrate that the abundance of some nirS-type

337 denitrifying bacterial communities in rhizosphere soils was increased due to T. melanosporum

338 inoculation. The previous study showed that the mycorrhiza and rhizobia assist plants with the

339 uptake of phosphorus and nitrogen, respectively (Heijden et al., 2008), which may suggest that the

340 T. melanosporum ectomycorrhizae accelerate the weathering of minerals and the degradation of

341 recalcitrant organic matter by enhancing the colonization of nirS-type denitrifying bacteria in

342 ectomycorrhizosphere soils (Berendsen et al., 2012; Deveau et al., 2016). Meanwhile, the relative

343 abundance of unclassified bacterial genera belonging to Gammaproteobacteria and

344 Betaproteobacteria were significantly lower in ectomycorrhizosphere soils $(P<0.05)$, which

345 demonstrated that the colonization of T. melanosporum decreased the relative abundance of some

346 nirS-type denitrifying bacterial genera in ectomycorrhizosphere soils.

347 Our work revealed that the Pseudomonas was the most abundant classified nirS-type

348 denitrifying bacteria in ectomycorrhizosphere soils, which are widely distributed in plant

349 rhizosphere soils and truffle orchard soils (Prieme et al., 2002; Sharma et al., 2005). Furthermore,

350 Pseudomonas were also detected in fruiting bodies of Tuber indicum, Tuber pseudoexcavatum,

351 Tuber sinoaestivum, Tuber huidongense and T. melanosporum (Ye et al., 2018; Roux et al., 2016).

352 Though the ascocarp of T. melanosporum itself may not be rich in Pseudomonas, it can somehow

353 acquire Pseudomonas and massive other nitrogen cycle-related bacteria (Antony-Babu et al.,

354 2013). And though these nitrogen cycle-related bacteria were carried in the ascocarp inoculum and

355 brought into the substrate, we still found some nirS-type denitrifying bacteria such as Unclassified

356 Gammaproteobacteria and Unclassified Betaproteobacteria significantly less abundant in 
357 ectomycorrhizosphere soils than in rhizosphere soils. These may imply that, if without the

358 bringing-in of these bacteria from the ascocarp to the soils, their relative abundance might be

359 lower. This further revealed that the presence of truffle mycelia inhibited the colonization of AOB

360 and some nirS-type denitrifying bacteria. The Pseudomonas such as Pseudomonas fluorescens

361 could enhance both the mycorrhization of T. melanosporum and the nutrient uptake of the host

362 plant (Dominguez et al., 2012; Citterio et al., 2001; Mamoun et al., 1992). The relative abundance

363 of Pseudomonas detected in ectomycorrhizosphere soils were significantly greater than that in

364 rhizosphere soils $(P<0.05)$, and the previous study also indicated Pseudomonas had greater

365 representation inside the brûlés compared with the outside (Mello et al., 2013). Therefore, we

366 hypothesized that $T$. melanosporum may improve the growth of the host plants by enhancing the

367 colonization of Pseudomonas in rhizosphere soils of the host plants in the initial symbiotic stage.

368 The ectomycorrhizosphere soils of the host plant contained a large number of Pseudomonas

369 species whose culture condition was unclear and needs further study. We also found that the

370 abundance of nirS-type denitrifying bacteria was much greater than that of AOB in the rhizosphere

371 soils of $C$. illinoinensis, and there were a large number of unclassified nitrogen cycling bacteria in

372 ectomycorrhizosphere soils. The dynamic evolution of other nitrogen cycling microorganism

373 including fungal and archaea communities over the process of ectomycorrhizal formation require

374 further exploration.

375 On account of sterilized seeds and substrates used in our study, bacteria in tap water and air 376 could then randomly get into the soil, and those who get early entrance may be more competitive

377 and dominant due to their earlier starts and more rapid reproduction. This may cause the levels of 378 specific AOB and nirS-type denitrifying bacteria vary greatly in different samples of the same 379 treatment. In fact, we did find that the number of certain OTUs differed greatly in 4 different 
380 samples in the same treatment. Therefore, the results obtained when the sample size was small (n $381=4)$ may not comprehensively reflect the true situation of all plants under the same culture 382 conditions. It is difficult to guarantee that the significant differences in bacterial communities 383 between two treatments were not accidental. We will set a larger number of samples in a treatment, 384 while by measuring the rate of nitrification and denitrification, the mycorrhizal degree of $T$.

385 melanosporum mycorrhizal synthesis, and the abundance of the dominant AOB and nirS-type 386 denitrifying bacteria (especially Nitrosococcus and Pseudomonas, whose abundances differed 387 greatly in ectomycorrhizosphere and rhizosphere), we could conduct some in-depth researches. 388 The subsequent work could also focus on analyzing the correlation of the above three, and explore 389 whether the dominant bacteria related to the nitrogen cycle at the initial stage of inoculation could 390 affect the mycorrhizal synthesis by changing the content of available nitrogen in the soil, in 391 addition, isolating and culturing these unclassified bacteria and learning their biological 392 characteristics.

\section{Conclusions}

394 In the current study, we found nirS-type denitrifying bacterial and AOB communities in $C$. 395 illinoinensis rhizosphere soils were significantly affected by $T$. melanosporum inoculation at the 396 early symbiotic stage, though the total nitrogen, nitrate-nitrogen and ammonium-nitrogen contents 397 of ectomycorrhizosphere soils were not different from those of rhizosphere soils. There was a 398 lower-abundance of $\mathrm{AOB}$ and greater-abundance of nirS-type denitrifying bacterial communities 399 in C. illinoinensis-T. melanosporum ectomycorrhizosphere soils compared with control treatment. 400 Proteobacteria was the dominant bacterial phylum, and the abundance of Nitrosomonas (AOB) 401 was significantly reduced because of $T$. melanosporum inoculation, while the abundance of 
402 Pseudomonas (nirS-type denitrifying bacteria) increased. This work furthers our understanding of 403 rhizosphere microecology and the cultivation of T. melanosporum-C. illinoinensis.

\section{References}

405 Antony-Babu S, Deveau A, Van-Nostrand JD, Zhou J, Le-Tacon F, Robin C, Frey-Klett P, Uroz 406 S. 2014. Black truffle associated bacterial communities during the development and maturation 407 of Tuber melanosporum ascocarps and putative functional roles. Environmental Microbiology, 408 16(9):2831-2847. DOI: 10.1111/1462-2920.12294

409 Azziz G, Monza J, Etchebehere C, and Irisarri P. 2017. nirS- and nirK-type denitrifier communities 410 are differentially affected by soil type, rice cultivar and water management. European Journal 411 of Soil Biology 78:20-28. DOI: 10.1016/j.ejsobi.2016.11.003

412 Barbieri E, Guidi C, Bertaux J, Freyklett P, Garbaye J, Ceccaroli P, Saltarelli R, Zambonelli A, 413 Stocchi V. 2007. Occurrence and diversity of bacterial communities in Tuber magnatum during 414 truffle maturation. Environmental Microbiology 9(9):2234-2246 DOI: 10.1111/j.1462$415 \quad 2920.2007 .01338 . x$

416 Berendsen RL, Pieterse CMJ, Bakker PAHM. 2012. The rhizosphere microbiome and plant health. 417 Trends in Plant Science 17(8) DOI: 10.1016/j.tplants.2012.04.001

418 Bonito G, Brenneman T, Vilgalys R. 2011. Ectomycorrhizal fungal diversity in orchards of 419 cultivated pecan (Carya illinoinensis; Juglandaceae). Mycorrhiza 21:601-612 DOI: $420 \quad 10.1007 / \mathrm{s} 00572-011-0368-0$

421 Bonito G, Trappe JM, Donovan S, Vilgalys R. 2011. The Asian black truffle Tuber indicum can 422 form ectomycorrhizas with North American host plants and complete its life cycle in non-native 423 soils. Fungal Ecology 4(1):83-93 DOI: 10.1016/j.funeco.2010.08.003

424 Braker G, Zhou J, Wu L, Devol AH, Tiedje JM. 2000. Nitrite reductase genes (nirK and nirS) as 
425 functional markers to investigate diversity of denitrifying bacteria in pacific northwest marine 426 sediment communities. Applied and Environmental Microbiology, 66(5):2096-2104 DOI: 427 10.1128/AEM.66.5.2096-2104.2000

428 Bremer C, Braker G, Matthies D, Reuter A, Engels C, Conrad R. 2007. Impact of plant functional 429 group, plant species, and sampling time on the composition of nirK-type denitrifier communities 430 in soil. Applied and Environmental Microbiology 73(21):6876-6884 DOI: $431 \quad$ 10.1128/AEM.01536-07

432 Caporaso JG, Kuczynski J, Stombaugh J, Bittinger K, Bushman FD, Costello EK, Fierer N, Peña 433 AG, Goodrich JK, Gordon JI. 2010. QIIME allows analysis of high-through put community 434 sequencing data. Nature 7(5): 335-336 DOI: 10.1038/nmeth.f.303

435 Citterio B, Malatesta M, Battistelli S, Marcheggiani F, Gazzanelli G. 2001. Possible involvement 436 of Pseudomonas fluorescens and Bacillaceae in structural modification of Tuber borchii fruit 437 bodies. Canadian Journal of Microbiology 47:264-268. 10.1139/w01-005

438 Conrad R. 1997. Soil microorganisms as controllers of atmospheric trace gases $\left(\mathrm{H}_{2}, \mathrm{CO}, \mathrm{CH}_{4}\right.$, 439 OCS, $\mathrm{N}_{2} \mathrm{O}$, and NO). Microbiological reviews 60(4):609-640 DOI: 10.1006/mpat.1996.0079

440 Core R, Null RDCT, Team R, Team TSUD, Coreteam R. 2011. A Language and Environment for 441 Statistical Computating. Available at https://www.R-project.org 14:12-21

442 Deveau A, Antony-Babu S, Le Tacon F, Robin C, Frey-Klett P, Uroz S. 2016. Temporal changes 443 of bacterial communities in the Tuber melanosporum ectomycorrhizosphere during ascocarp 444 development. Mycorrhiza 26, 389-399 DOI: 10.1007/s00572-015-0679-7

445 Dominguez JA, Martin A, Anriquez A, Albanesi A. 2012. The combined effects of Pseudomonas 446 fluorescens and Tuber melanosporum on the quality of Pinus halepensis seedlings. Mycorrhiza 447 22:429-436 DOI: 10.1007/s00572-011-0420-0 
448 Donnini D, Benucci GMN, Bencivenga M, Falini LB. 2014. Quality assessment of truffle449 inoculated seedlings in Italy: Proposing revised parameters for certification. Forest Systems 450 23(2):385-393 DOI: $10.5424 /$ fs/2014232-05029

451 Doornbos RF, van Loon LC, Bakker PAHM. 2012. Impact of root exudates and plant defense 452 signaling on bacterial communities in the rhizosphere. A review. Agronomy for Sustainable 453 Development 32(1):227-243 DOI: 10.1007/s13593-011-0028-y

454 Edgar RC. 2013. UPARSE: highly accurate OTU sequences from microbial amplicon reads. $455 \quad$ Nature Methods DOI: 10:184. 10.1038/NMETH.2604

456 Fu Y, Li X, Li Q, Wu H, Xiong C, Geng Q, Sun H, Sun Q. 2016. Soil microbial communities of 457 three major Chinese truffles in Southwest China. Canadian Journal of Microbiology:2016-2139 458 DOI: $10.1139 /$ cjm-2016-0139

459 Garcia-Barreda S, Molina-Grau S, Forcadell R, Sánchez S, Reyna S. 2017. Long-term soil 460 alteration in historical charcoal hearths affects Tuber melanosporum mycorrhizal development 461 and environmental conditions for fruiting. Mycorrhiza DOI: 10.1007/s00572-017-0773-0

462 Garcia-Barreda S, Reyna S. 2012. Below-ground ectomycorrhizal community in natural Tuber 463 melanosporum truffle grounds and dynamics after canopy opening. Mycorrhiza 22:361-369 464 DOI: $10.1007 / \mathrm{s} 00572-011-0410-2$

465 Geng LY, Wang XH, Yu FQ, Deng XJ, Tian XF, Shi XF, Xie XD, Liu PG, Shen YY. 2009. 466 Mycorrhizal synthesis of Tuber indicum with two indigenous hosts, Castanea mollissima and 467 Pinus armandii. Mycorrhiza 19(7):461-467 DOI: 10.1007/s00572-009-0247-0

468 Gleeson DB, Müller C, Banerjee S, Ma W, Siciliano SD, Murphy DV. 2010. Response of ammonia 469 oxidizing archaea and bacteria to changing water filled pore space. Soil Biology \& Biochemistry 470 42:1888-1891 DOI: 10.1016/j.soilbio.2010.06.020 
471 Green SJ, Prakash O, Gihring TM, Akob DM, Jasrotia P, Jardine PM, Watson DB, Brown SD, 472 Palumbo AV, Kostka JE. 2010. Denitrifying bacteria isolated from terrestrial subsurface 473 sediments exposed to mixed-waste contamination. Applied \& Environmental Microbiology 474 76:3244-3254 DOI: 10.1128/AEM.03069-09

475 Gregory LG, Bond PL, Richardson DJ, Spiro S. 2003. Characterization of a nitrate-respiring 476 bacterial community using the nitrate reductase gene (narG) as a functional marker. 477 Microbiology 149:229-237 DOI: 10.1099/mic.0.25849-0

478 Healy RA, Zurier H, Bonito G, Smith ME, Pfister DH. 2016. Mycorrhizal detection of native and 479 non-native truffles in a historic arboretum and the discovery of a new North American species, 480 Tuber arnoldianum sp. nov. Mycorrhiza 26:781 DOI: 10.1007/s00572-016-0713-4

481 Hu HW, Macdonald CA, Trivedi P, Holmes B, Bodrossy L, He JZ, Singh BK. 2015. Water 482 addition regulates the metabolic activity of ammonia oxidizers responding to environmental 483 perturbations in dry subhumid ecosystems. Environmental Microbiology DOI: 17. 484 $10.1111 / 1462-2920.12481$

Hui T, Yan K, Zhang L, Chi F, Li Q, Lian S, and Wei D. 2010. Diversity analysis of nitrite 486 reductase genes (nirS) in black soil under different long-term fertilization conditions. Annals of 487 Microbiology 60:97-104. 10.1007/s13213-009-0009-4

488 Jung SC, Martinez-Medina A, Lopez-Raez JA, Pozo MJ. 2012. Mycorrhiza-induced resistance and 489 priming of plant defenses. Journal of Chemical Ecology DOI: 38:651-664. 10.1007/s10886$490 \quad 012-0134-6$

491 Kim OS, Imhoff JF, Witzel KP, Junier P. 2011. Distribution of denitrifying bacterial communities 492 in the stratified water column and sediment-water interface in two freshwater lakes and the 493 Baltic Sea. Aquatic Ecology 45:99-112 DOI: 10.1007/s10452-010-9335-7 
494 Kowalchuk GA, Stephen JR. 2001. Ammonia-oxidizing bacteria: a model for molecular microbial 495 ecology. Annual Review of Microbiology DOI: 55:485. 10.1146/annurev.micro.55.1.485

496 Kües U, Martin F. 2011. On the road to understanding truffles in the underground. 48(6):560 DOI:

$497 \quad$ 10.1016/j.fgb.2011.02.002

498 Li Q, Zhao J, Xiong C, Li X, Chen Z, Li P, Huang W. 2017. Tuber indicum shapes the microbial 499 communities of ectomycorhizosphere soil and ectomycorrhizae of an indigenous tree (Pinus 500 armandii). Plos One 12(4):e175720 DOI: 10.1371/journal.pone.0175720

501 Li Q, Yan LJ, Ye L, Zhou J, Zhang B, Peng WH, Zhang XP. 2018. Chinese black truffle (Tuber 502 indicum) alters the ectomycorrhizosphere and endoectomycosphere microbiome and metabolic 503 profiles of the host tree Quercus aliena. Front. Microbiol. 9:2202 DOI: $504 \quad 10.3389 /$ fmicb.2018.02202

505 Li XL, Zhang XP, Yang M, Yan LJ, Liu CY. 2019. Tuber borchii sapes the etomycorrhizosphere 506 mcrobial cmmunities of Corylus avellana. Mycobiology 47(2):1-11 DOI: 507 $10.1080 / 12298093.2019 .1615297$

508 Li Y, Chen Z, He J, Wang Q, Shen C, Ge Y. 2018. Ectomycorrhizal fungi inoculation alleviates 509 simulated acid rain effects on soil ammonia oxidizers and denitrifiers in Masson pine forest. 510 Environmental Microbiology DOI: 10.1111/1462-2920.14457

511 Lindahl B, Ihrmark K, Boberg J, Trumbore S, Hogberg P, Stenlid J, Finlay R. 2006. Spatial 512 separation of litter decomposition and mycorrhizal nitrogen uptake in a boreal forest. New 513 Phytologist 173:611-620 DOI: 10.1111/j.1469-8137.2006.01936.x

514 Lu RK. 1999. Soil and agro-chemical analytical methods. China Agricultural Science and 515 Technology Press: Beijing, China.

516 Mamoun M, Olivier JM. 1992. Effect of soil Pseudomonads on colonization of hazel roots by the 
517 ecto-mycorrhizal species Tuber melanosporum and its competitors. Plant \& Soil 139:265-273

$518 \quad$ DOI: $10.1007 / \mathrm{bf00009318}$

519 Mao Y, Yannarell AC, Mackie RI. 2011. Changes in N-transforming archaea and bacteria in soil 520 during the establishment of bioenergy crops. Plos One 6 DOI: 10.1371/journal.pone.0024750

521 Marozzi G, Sánchez S, Benucci G M N, Bonito G, Falini L B, Albertini E, and Donnini D. 2017.

522 Mycorrhization of pecan (Carya illinoinensis) with black truffles: Tuber melanosporum and 523 Tuber brumale. Mycorrhiza 27:303-309 DOI: 10.1007/s00572-016-0743-y

524 Mello A, Ding GC, Piceno YM, Napoli C, Tom LM, DeSantis TZ, Andersen GL, Smalla K, Paola 525 B. 2013. Truffle brûlés have an impact on the diversity of soil bacterial communities. Plos One 526 8(4):e61945 DOI: 10.1371/journal.pone.0061945

527 Michotey V, Méjean V, Bonin P. 2000. Comparison of methods for quantification of cytochrome 528 cd1-denitrifying bacteria in environmental marine samples. Applied \& Environmental 529 Microbiology 66:1564-1571 DOI: 10.1128/AEM.66.4.1564-1571.2000

530 Petersen DG, Blazewicz SJ, Firestone M, Herman DJ, Turetsky M, Waldrop M. 2012. Abundance 531 of microbial genes associated with nitrogen cycling as indices of biogeochemical process rates 532 across a vegetation gradient in Alaska. Environmental Microbiology 14(4):993-1008 DOI:

$533 \quad 10.1111 / \mathrm{j} .1462-2920.2011 .02679 . x$

534 Ponce RA, Agreda T, Agueda B, Aldea J, Modrego MP. 2014. Soil physical properties influence 535 "black truffle" fructification in plantations. Mycorrhiza DOI: 24. 10.1007/s00572-014-0558-7

536 Purkhold U, Pommerening-Röser A, Juretschko S. 2000. Phylogeny of all recognized species of 537 ammonia oxidizers based on comparative 16S rRNA and amo $A$ sequence analysis: implications 538 for molecular diversity surveys. Applied and Environmental Microbiology 12:5368-5382 DOI: 539 10.1128/AEM.66.12.5368-5382.2000 
540 Prieme A, Braker G, Tiedje JM. 2002. Diversity of nitrite reductase (nirK and nirS) gene fragments

541 in forested upland and wetland soils. Applied \& Environmental Microbiology 68:1893-1900

542 DOI: 10.1128/AEM.68.4.1893-1900.2002

543 Reyna S, Garcia-Barreda S. 2014. Black truffle cultivation: A global reality. Forest Systems 544 23:317-328 DOI: $10.5424 /$ fs/2014232-04771

545 Roux C, Tournier E, Lies A, Sanguin H, Chevalier G, Duponnois R. 2016. Bacteria of the genus 546 Rhodopseudomonas (Bradyrhizobiaceae): obligate symbionts in mycelial cultures of the black 547 truffles Tuber melanosporum and Tuber brumale. Springerplus, 5(1):1085 DOI: $548 \quad 10.1186 / \mathrm{s} 40064-016-2756-6$

549 Ruan YL, Wood BW, Payne JA. 1992. Chinese hickory: an emerging nut-tree crop. Fruit Varieties $550 \quad$ Journal.

551 Seitzinger S, Harrison JA, Bã Hlke JK, Bouwman AF, Lowrance R, Peterson B, Tobias C, Van 552 Drecht G. 2006. Denitrification across landscapes and waterscapes: a synthesis. Ecological 553 Applications 16:2064-2090 DOI: 10.1890/1051-0761(2006)016[2064:dalawa]2.0.co;2

554 Semeniuk G. 2008. Common leafspot of alfalfa: ascospore germination and disease development 555 in relation to moisture and temperature. Journal of Phytopathology DOI: 110:281-289. $556 \quad 10.1111 / \mathrm{j} .1439-0434.1984 . t b 00068 . x$

557 Shapleigh JP. 2006. The dnitrifying pokaryotes. Prokaryotes 2006:769-792 DOI: 10.1007/0-387558 30742-7_23

559 Sharma S, Aneja MK, Mayer J, Munch JC, Schloter M. 2005. Diversity of transcripts of nitrite 560 reductase genes (nirK and nirS) in rhizospheres of Grain Legumes. Appl Environ Microbiol 561 71:2001-2007 DOI: 10.1128/AEM.71.4.2001-2007.2005

562 Sparks D. 1992. Pecan cultivars: the orchard's foundation. 
563 Sterkenburg E, Clemmensen KE, Ekblad A, Finlay RD. 2018. Contrasting effects of 564 ectomycorrhizal fungi on early and late stage decomposition in a boreal forest. DOI: $565 \quad 10.1038 / \mathrm{s} 41396-018-0181-2$.

566 Tanja M, Salzberg SL. 2011. FLASH: fast length adjustment of short reads to improve genome 567 assemblies. Bioinformatics:21 DOI: 10.1093/bioinformatics/btr507

568 Thamdrup B. 2012. New pathways and processes in the global nitrogen cycle. Annual Review of 569 Ecology Evolution and Systematics 43:407-428 DOI: 10.1146/annurev-ecolsys-102710-145048

570 Throbäck IN, Enwall K, Jarvis Å, Hallin S. 2004. Reassessing PCR primers targeting, and genes 571 for community surveys of denitrifying bacteria with DGGE. Fems Microbiology Ecology 572 49:401-417 DOI: 10.1016/j.femsec.2004.04.011

573 Trappa JM, Jumpponen MA, Cázares E. 1996. NATS truffle and truffle-like fungi. II . Tuber lyonii 574 (=T. Texense), with a key to the spiny-spored Tuber species groups. Mycotaxon. 60: 365-372 575 DOI: $10.1109 /$ JSSC.2003.814437

576 Van der Heijden MGA, Bardgett RD, and Van Straalen NM. 2008. The unseen majority: soil 577 microbes as drivers of plant diversity and productivity in terrestrial ecosystems. Ecology Letters $578 \quad 11: 296-310$ DOI: 10.1111/j.1461-0248.2007.01139.x

579 Wakeling LT, Mason RL, D'Arcy BR, Caffin NA. 2001. Composition of pecan cultivars Wichita 580 and Western Schley grown in Australia. Journal of Agricultural and Food Chemistry 49(3): 581 1277-1281 DOI: 10.1021/jf000797d

582 Wan SP, Yu FQ, Tang L, Wang R, Wang Y, Liu PG, Wang XH, Zheng Y. 2016. Ectomycorrhizae 583 of Tuber huidongense and T. liyuanum with Castanea mollissima and Pinus armandii. $584 \quad$ Mycorrhiza 26:1-8.

585 Wang Q, Garrity GM, Tiedje JM, Cole JR. 2007. Naive bayesian classifier for rapid assignment 
586 of rRNA sequences into the new bacterial taxonomy. Applied \& Environmental Microbiology

$587 \quad$ 73:5261-5267 DOI: 10.1128/aem.00062-07

588 Wang S, Wang Y, Feng X, Zhai L, Zhu G. 2011. Quantitative analyses of ammonia-oxidizing 589 archaea and bacteria in the sediments of four nitrogen-rich wetlands in China. Applied 590 Microbiology and Biotechnology 90(2), 779-787 DOI: 10.1007/s00253-011-3090-0

591 Wedén C, Chevalier G, Danell E. 2004. Tuber aestivum (syn. T. uncinatum) biotopes and their 592 history on Gotland, Sweden. Mycological Research 108(3):304-310 DOI: $593 \quad 10.1017 / \mathrm{s} 0953756204009256$

594 Wen X, Meng W, Ti J, Yao W, Fu C. 2016. Bacterial community composition in the rhizosphere 595 of maize cultivars widely grown in different decades. Biology \& Fertility of Soils 53:1-9 DOI: $596 \quad 10.1007 / \mathrm{s} 00374-016-1169-6$

597 Yang M, Zou J, Liu C, Xiao Y, Zhang X, Yan L, Ye L, Tang P, Li XL. 2019. Chinese white truffles 598 shape the ectomycorrhizal microbial communities of Corylus avellana. Annals of Microbiology 599 69:553-565 DOI: 10.1007/s13213-019-1445-4

600 Ye L, Li Q, Fu Y, Pierre S, Tan H, Zou J, Zhang B, Li XL. 2018. Host species effects on bacterial 601 communities associated with the fruiting bodies of Tuber species from the Sichuan Province in 602 Southwest China. Mycological Progress DOI: 10.1007/s11557-018-1397-2

603 Yoshida M, Ishii S, Otsuka S, Senoo K. 2010. NirK-harboring denitrifiers are more responsive to 604 denitrification-inducing conditions in rice paddy soil than nirS-harboring bacteria. Microbes \& 605 Environments 25:45-48 DOI: 10.1264/jsme2.ME09160

606 Yu Z, Liu J, Li Y, Jin J, Liu X, Wang G. 2018. Impact of land use, fertilization and seasonal 607 variation on the abundance and diversity of nirS-type denitrifying bacterial communities in a 608 Mollisol in Northeast China. European Journal of Soil Biology DOI: 85:4-11. 
$609 \quad 10.1016 / j$.ejsobi.2017.12.001

610 Zhang X, Ye L, Kang Z, Zou J, Zhang X, Li X. 2019. Mycorrhization of Quercus acutissima with

611 Chinese black truffle significantly altered the host physiology and root-associated microbiomes.

$612 \quad$ Peer $J$ 7:e6421 DOI: 10.7717/peerj.6421

613 Zumft WG. 1997. Cell biology and molecular basis of denitrification. Microbiology and Molecular

614 Biology Reviews 61(4):533-616 DOI: 10.1016/j.ccr.2004.08.030

615 


\section{Table $\mathbf{1}$ (on next page)}

Physical and chemical properties of soil samples.

$\mathrm{OM}$, organic matter; $\mathrm{TN}$, total nitrogen; $\mathrm{NH}_{4}{ }^{+}-\mathrm{N}$, ammonium-nitrogen; $\mathrm{NO}_{3}{ }^{-}-\mathrm{N}$, nitrate-nitrogen; AK, available potassium; AP, available phosphorus. FH, ectomycorrhizosphere soil (the rhizosphere soil of Carya illinoinensis mycorrhized with Tuber melanosporum); CK, the rhizosphere soil of Carya illinoinensis without Tuber melanosporum partner. Values are mean \pm standard deviation $(n=4)$. There is no significant difference between two treatments $(P>$ 0.05). 
1

\begin{tabular}{cccccccc}
\hline Sample & $\mathbf{p H}$ & $\mathbf{O M}(\mathbf{g} / \mathbf{k g})$ & $\mathbf{T N}(\mathbf{g} / \mathbf{k g})$ & $\begin{array}{l}\mathbf{N H}_{4}^{+}-\mathbf{N} \\
(\mathbf{m g} / \mathbf{k g})\end{array}$ & $\begin{array}{l}\mathbf{N O}_{3^{-}-\mathbf{N}} \\
(\mathbf{m g} / \mathbf{k g})\end{array}$ & $\mathbf{A K}(\mathbf{m g} / \mathbf{k g})$ & $\mathbf{A P}(\mathbf{m g} / \mathbf{k g})$ \\
\hline $\mathbf{C K}$ & $9.48 \pm 0.06$ & $37.23 \pm 1.63$ & $1.08 \pm 0.03$ & $10.80 \pm 0.45$ & $11.36 \pm 0.12$ & $199.52 \pm 31.15$ & $18.20 \pm 0.51$ \\
$\mathbf{F H}$ & $9.40 \pm 0.02$ & $34.19 \pm 1.23$ & $0.95 \pm 0.04$ & $12.09 \pm 0.07$ & $11.97 \pm 0.04$ & $244.74 \pm 10.09$ & $18.92 \pm 1.49$ \\
\hline
\end{tabular}




\section{Table 2 (on next page)}

Community richness and diversity indices of ammonia-oxidizing bacteria and nirS-type denitrifying bacteria in rhizosphere soil with or without Tuber melanosporum partner.

FH, ectomycorrhizosphere soil (the rhizosphere soil of Carya illinoinensis mycorrhized with Tuber melanosporum). CK, the rhizosphere soil of Carya illinoinensis without Tuber melanosporum partner. Values are mean \pm standard deviation $(n=4)$. "** indicates significant difference between samples $(P<0.05)$. 


\begin{tabular}{cccccccc}
\hline Samples & & $\begin{array}{c}\text { Observed } \\
\text { species }\end{array}$ & Simpson & Shannon & ACE & Chao1 & Coverage \\
& CK & $56.75 \pm 15.21$ & $0.32 \pm 0.04$ & $1.62 \pm 0.15$ & $58.68 \pm 2.61$ & $57.22 \pm 6.63$ & 0.99 \\
AOB & FH & $46.00 \pm 10.92$ & $0.45 \pm 0.15$ & $1.32 \pm 0.19^{*}$ & $48.13 \pm 8.17^{*}$ & $46.55 \pm 5.09^{*}$ & 0.99 \\
\cline { 3 - 8 } & T-statistic & 1.148 & -1.722 & 2.482 & 2.460 & 2.551 & 0.069 \\
& P-value & 0.295 & 0.136 & 0.048 & 0.049 & 0.043 & 0.947 \\
\cline { 2 - 8 } & CK & $175.00 \pm 14.38$ & $0.16 \pm 0.05$ & $2.55 \pm 0.16$ & $188.43 \pm 10.19$ & $179.61 \pm 14.37$ & 0.99 \\
$\begin{array}{c}\text { nirS } \text {-type } \\
\text { denitrifying } \\
\text { bacteria }\end{array}$ & FH & $193.50 \pm 40.51$ & $0.13 \pm 0.03$ & $2.80 \pm 0.08^{*}$ & $204.27 \pm 7.73^{*}$ & $196.39 \pm 40.51^{*}$ & 0.99 \\
\cline { 2 - 8 } & T-statistic & -0.861 & 0.928 & -2.675 & -2.584 & -2.475 & -0.047 \\
\hline
\end{tabular}

1 


\section{Table 3 (on next page)}

The relative abundance of the most abundant ammonia-oxidizing and nirS-type denitrifying bacterial phyla in rhizosphere soil with or without Tuber melanosporum partner

$\mathrm{FH}$, ectomycorrhizosphere soil (the rhizosphere soil of Carya illinoinensis mycorrhized with Tuber melanosporum). CK, the rhizosphere soil of Carya illinoinensis without Tuber melanosporum partner. Values are mean \pm standard deviation $(n=4)$. "** indicates significant difference between samples $(P<0.05)$. 


\begin{tabular}{cccccc}
\hline & Phyla & CK & FH & T-statistic & P-value \\
\hline \multirow{2}{*}{ AOB } & Proteobacteria & $98.59 \% \pm 0.01$ & $84.93 \% \pm 0.13^{*}$ & 2.467 & 0.049 \\
& Unclassified Bacteria & $1.41 \% \pm 0.01$ & $15.07 \% \pm 0.13^{*}$ & -2.594 & 0.041 \\
\cline { 2 - 6 } $\begin{array}{c}\text { nirS-type } \\
\text { denitrifying } \\
\text { bacteria }\end{array}$ & Proteobacteria & $9.49 \% \pm 0.12$ & $8.69 \% \pm 0.02$ & 0.135 & 0.897 \\
& No rank Bacteria & $33.25 \% \pm 0.08$ & $51.10 \% \pm 0.12$ & -2.154 & 0.074 \\
& Unclassified Bacteria miscellaneous & $0.04 \% \pm 0.00$ & $0.03 \% \pm 0.00$ & 0.308 & 0.769 \\
\hline
\end{tabular}




\section{Table 4 (on next page)}

The relative abundance of the most abundant ammonia-oxidizing and nirS-type denitrifying bacterial genera in rhizosphere soil with or without Tuber melanosporum partner.

FH, ectomycorrhizosphere soil (the rhizosphere soil of Carya illinoinensis mycorrhized with Tuber melanosporum). CK, the rhizosphere soil of Carya illinoinensis without Tuber melanosporum partner. Values are mean \pm standard deviation $(n=4)$. "** indicates significant difference between samples $(P<0.05)$. 


\begin{tabular}{|c|c|c|c|c|c|}
\hline & Genera & $\mathbf{C K}$ & FH & T-statistic & P-value \\
\hline \multirow{6}{*}{ AOB } & Nitrosospira & $55.38 \% \pm 0.42$ & $57.90 \% \pm 0.38$ & -0.089 & 0.932 \\
\hline & Nitrosomonas & $39.99 \% \pm 0.41$ & $25.12 \% \pm 0.28$ & 0.600 & 0.573 \\
\hline & Nitrosococcus & $0.12 \% \pm 0.00$ & $0.00 \% \pm 0.00 *$ & 2.509 & 0.046 \\
\hline & Unclassified Betaproteobacteria & $1.93 \% \pm 0.02$ & $0.85 \% \pm 0.01 *$ & 2.533 & 0.044 \\
\hline & Unclassified Bacteria & $1.41 \% \pm 0.01$ & $15.07 \% \pm 0.13 *$ & -4.409 & 0.005 \\
\hline & Unclassified Nitrosomonadales & $0.98 \% \pm 0.02$ & $0.97 \% \pm 0.01$ & 0.011 & 0.991 \\
\hline \multirow{9}{*}{$\begin{array}{c}\text { nirS-type } \\
\text { denitrifying } \\
\text { bacteria }\end{array}$} & No rank Bacteria & $33.25 \% \pm 0.08$ & $51.10 \% \pm 0.12$ & -1.940 & 0.102 \\
\hline & Unclassified Bacteria & $57.22 \% \pm 0.14$ & $40.18 \% \pm 0.11$ & 1.934 & 0.101 \\
\hline & Unclassified Proteobacteria & $3.44 \% \pm 0.02$ & $7.16 \% \pm 0.01$ & -2.268 & 0.095 \\
\hline & Unclassified Gammaproteobacteria & $3.6 \% \pm 0.07$ & $0.00 \% \pm 0.00 *$ & 2.910 & 0.027 \\
\hline & Unclassified Betaproteobacteria & $1.98 \% \pm 0.03$ & $0.51 \% \pm 0.00 *$ & 5.040 & 0.015 \\
\hline & Rhodanobacter & $0.33 \% \pm 0.01$ & $0.35 \% \pm 0.00$ & -0.061 & 0.953 \\
\hline & Pseudomonas & $0.03 \% \pm 0.00$ & $0.46 \% \pm 0.00 *$ & -2.541 & 0.017 \\
\hline & Magnetospirillum & $0.01 \% \pm 0.00$ & $0.01 \% \pm 0.00$ & -0.049 & 0.963 \\
\hline & Rubrivivax & $0.01 \% \pm 0.00$ & $0.04 \% \pm 0.00$ & -0.981 & 0.396 \\
\hline
\end{tabular}




\section{Figure 1}

Morphological features of Carya illinoinensis root in association with or without Tuber melanosporum.

(a) Ectomycorrhizae of Tuber melanosporum, Scale bar $=500 \mu \mathrm{m}$; $\square \mathrm{b} \square$ Root of Carya illinoinensis without Tuber melanosporum, Scale bar =700 $\mu \mathrm{m}$; (c) Mantle with cystidia , Scale bar =65 $\mu \mathrm{m}$; (d) Mantle cell of ectomycorrhizae, Scale bar $=10 \mu \mathrm{m}$.

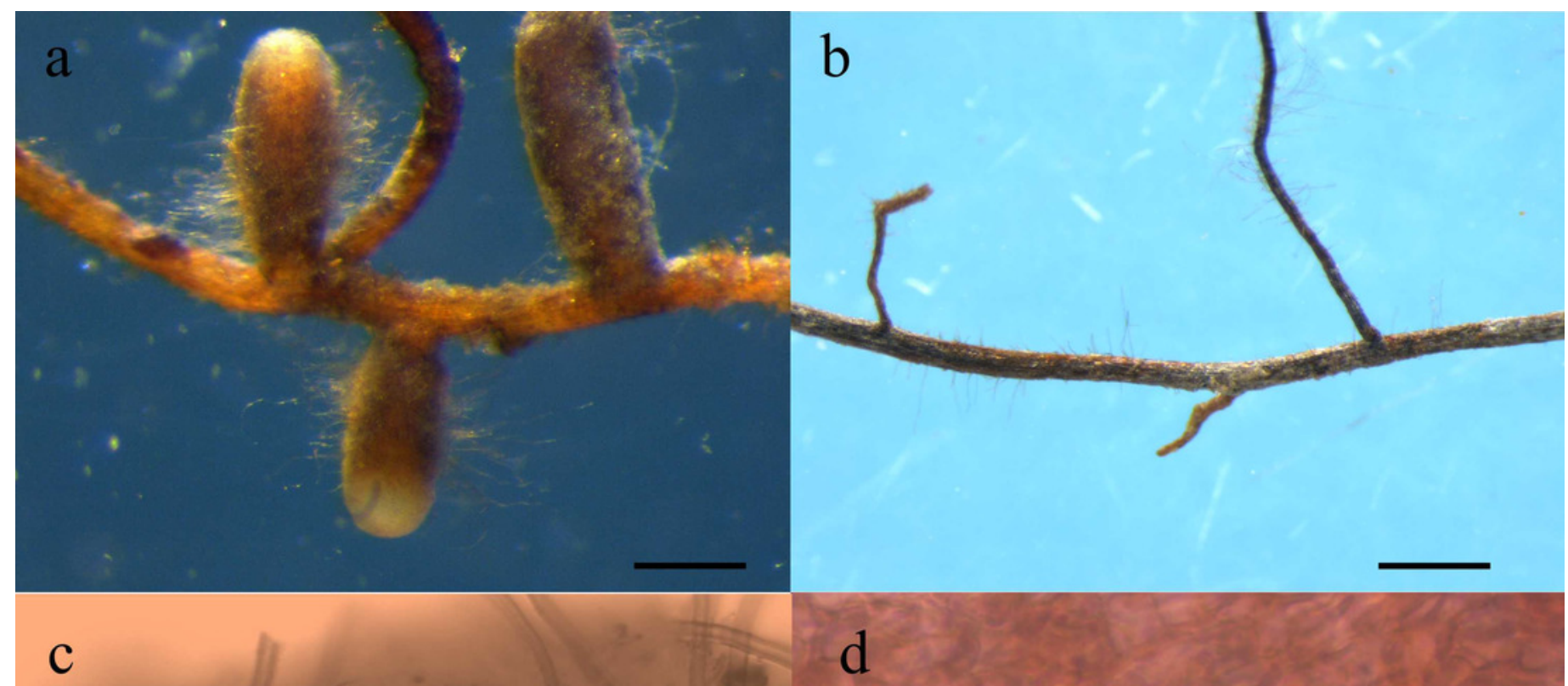


Figure 2

Rarefaction curves for ammonia-oxidizing bacterial (a) and nirS-type denitrifying bacterial (b) OTU diversity in different samples.

$\mathrm{FH}$, ectomycorrhizosphere soil (the rhizosphere soil of Carya illinoinensis mycorrhized with Tuber melanosporum). CK, the rhizosphere soil of Carya illinoinensis without Tuber melanosporum partner.

a

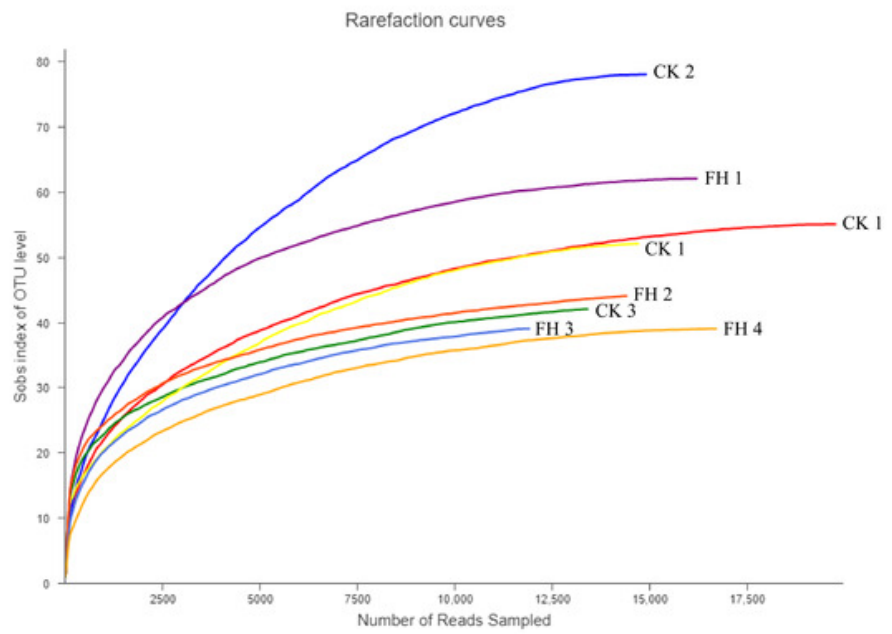

$\mathrm{b}$

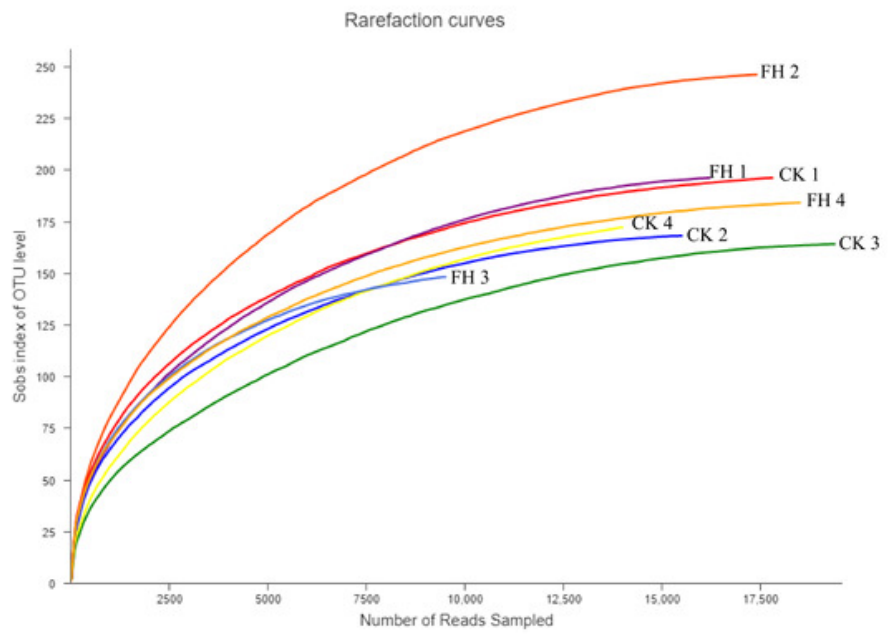




\section{Figure 3}

Numbers of shared and unique ammonia-oxidizing bacterial (a) and nirS-type denitrifying bacterial (b) Operational Taxonomic Units (OTUs).

$\mathrm{FH}$, ectomycorrhizosphere soil (the rhizosphere soil of Carya illinoinensis mycorrhized with Tuber melanosporum). CK, the rhizosphere soil of Carya illinoinensis without Tuber melanosporum partner.

$\mathrm{a}$

\section{$\mathrm{FH}$}

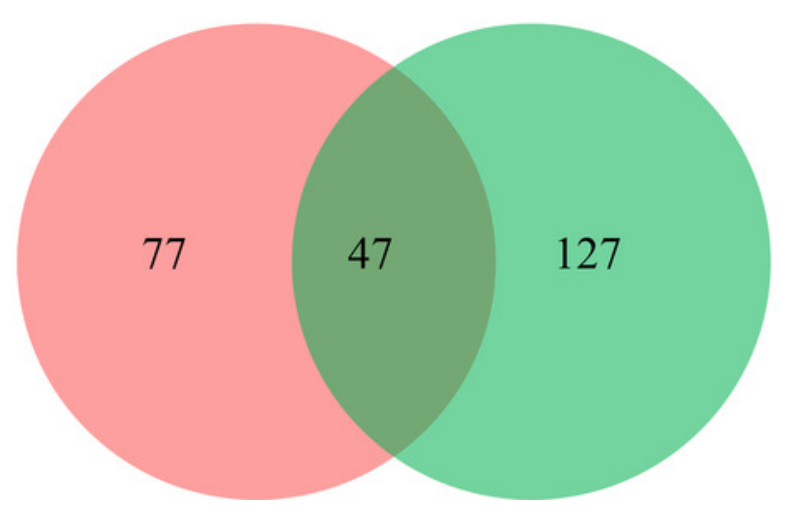

b

\section{$\mathrm{FH}$}

CK

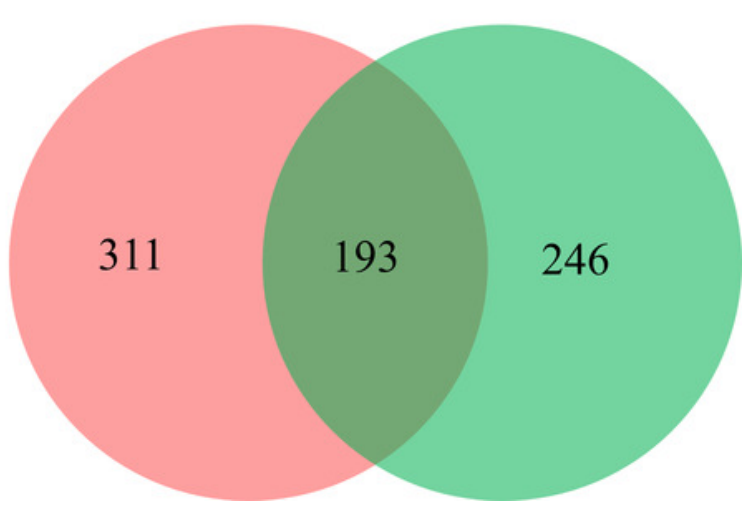


Figure 4

Taxonomic composition of ammonia-oxidizing bacterial (a) and nirS-type denitrifying bacterial (b) communities at the phylum levels.

$\mathrm{FH}$, ectomycorrhizosphere soil (the rhizosphere soil of Carya illinoinensis mycorrhized with Tuber melanosporum). CK, the rhizosphere soil of Carya illinoinensis without Tuber melanosporum partner. 
a

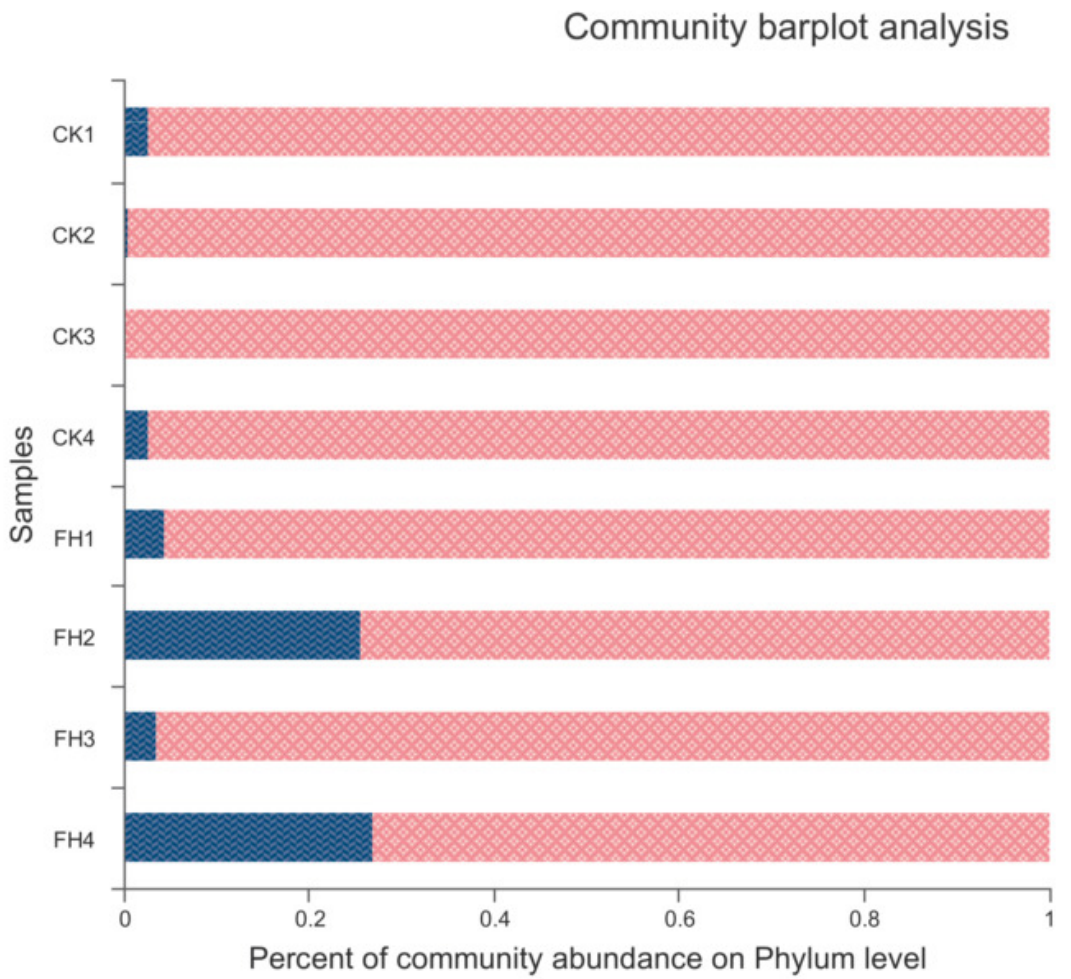

\section{b}

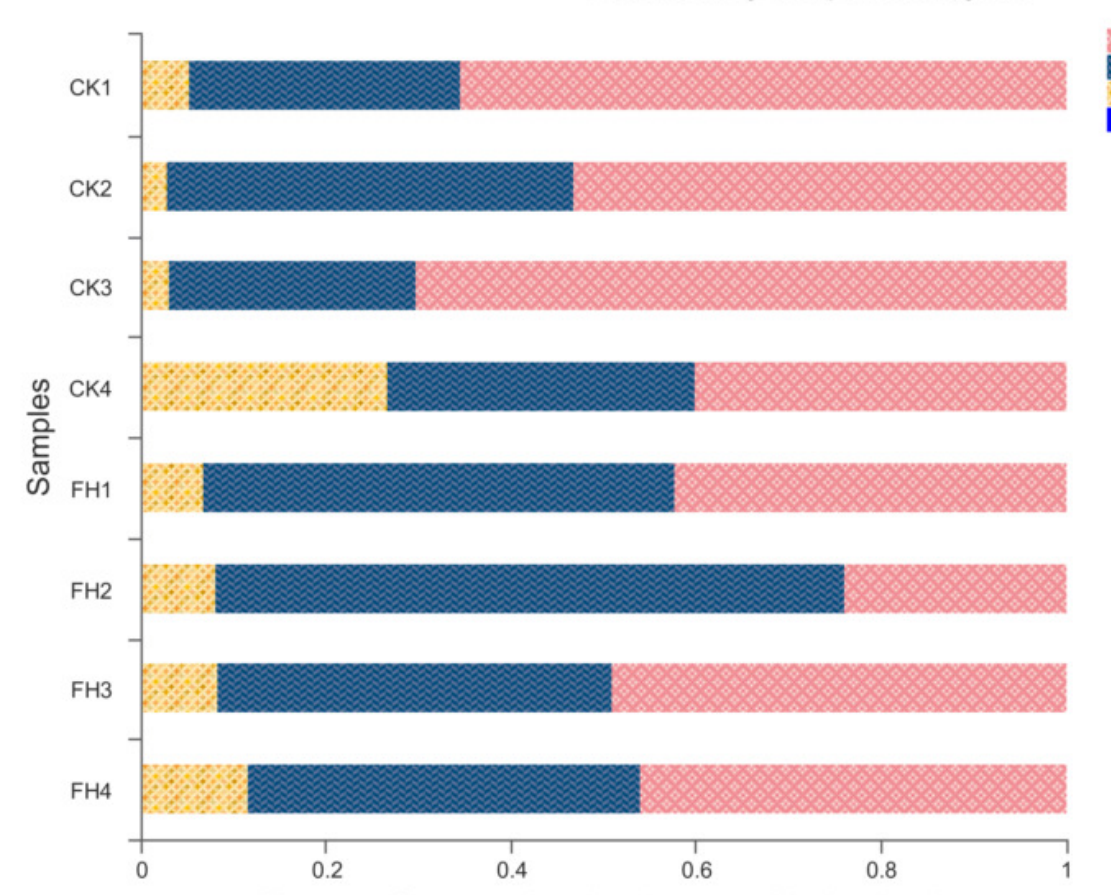

Percent of community abundance on Phylum level
Proteobacteria

unclassified_k_norank_d_Bacteria
unclassified_Bacteria

norank_Bacteria

Proteobacteria

others 
Figure 5

Taxonomic composition of ammonia-oxidizing bacterial (a) and nirS-type denitrifying bacterial (b) communities at the genus levels.

$\mathrm{FH}$, ectomycorrhizosphere soil (the rhizosphere soil of Carya illinoinensis mycorrhized with Tuber melanosporum). CK, the rhizosphere soil of Carya illinoinensis without Tuber melanosporum partner. 


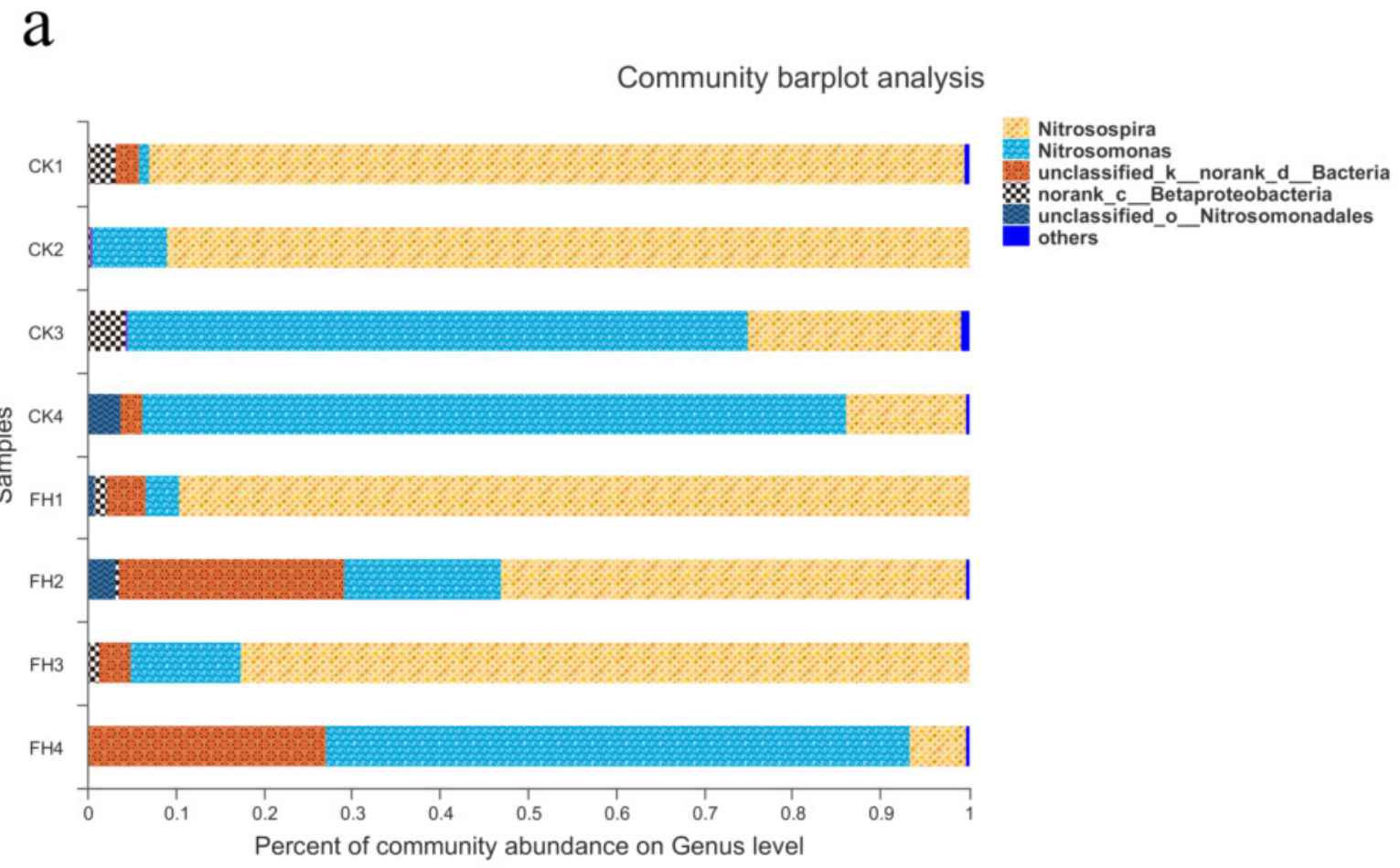

b

Community barplot analysis

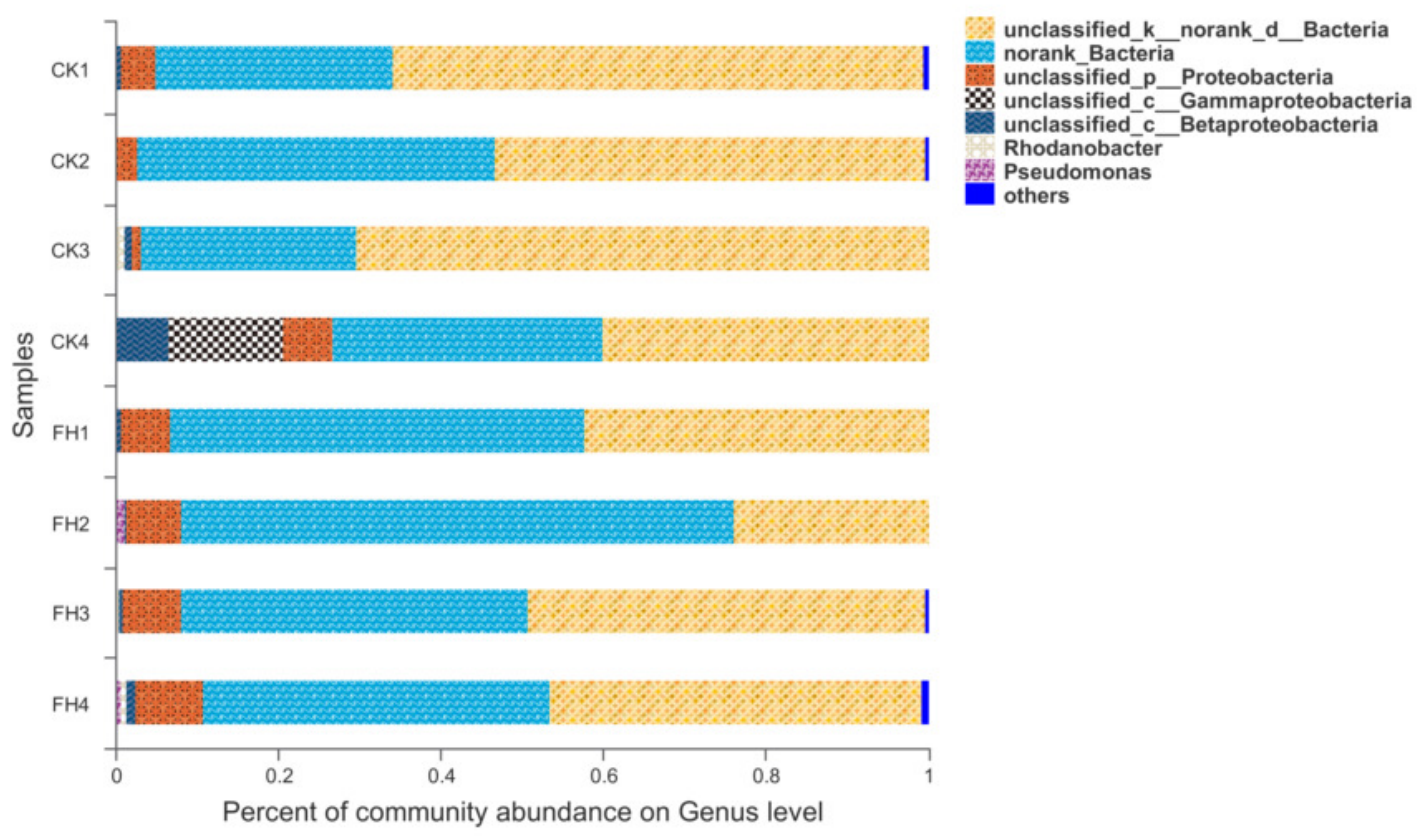




\section{Figure 6}

Principal component analysis (PCA) of ammonia-oxidizing bacterial (a) and nirS-type denitrifying bacterial (b) communities.

$\mathrm{FH}$, ectomycorrhizosphere soil (the rhizosphere soil of Carya illinoinensis mycorrhized with Tuber melanosporum). CK, the rhizosphere soil of Carya illinoinensis without Tuber melanosporum partner.

a

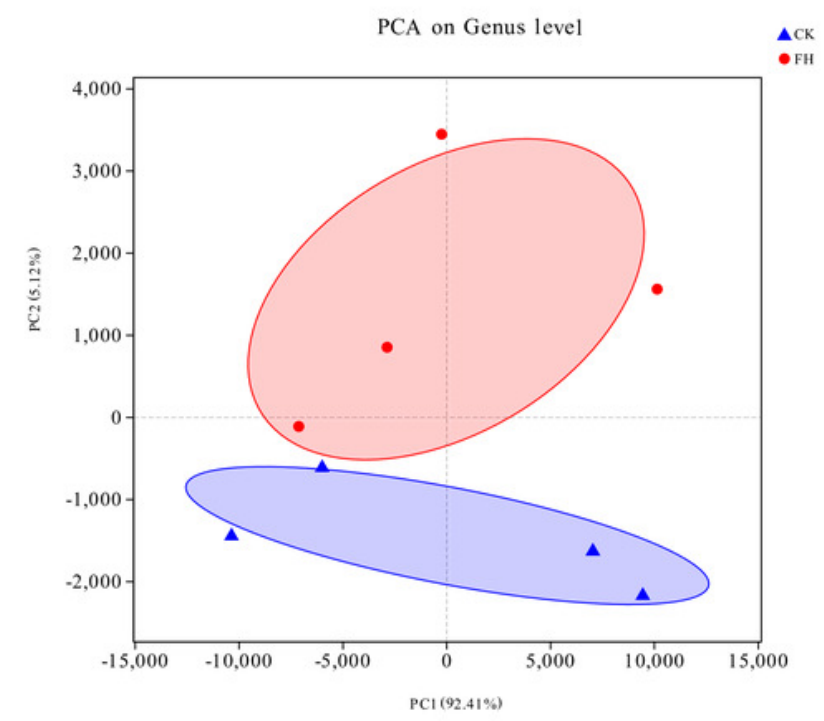

$\mathrm{b}$

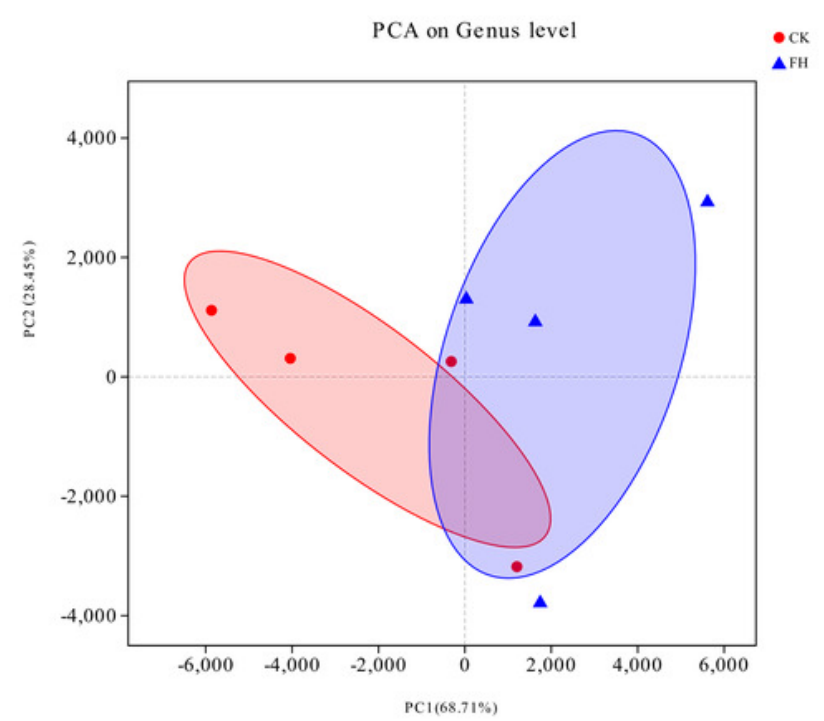

